\title{
Production and characterization of a new mango distilled beverage
}

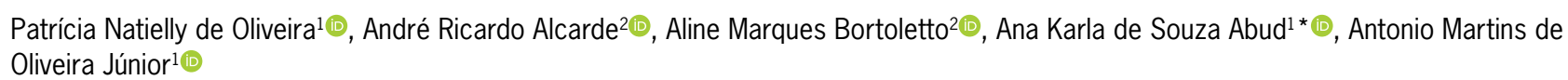

\author{
Universidade Federal de Sergipe - Depto. de Tecnologia de \\ Alimentos, Av. Marechal Rondon, s/n - 49100-000 - São \\ Cristóvão, SE - Brasil. \\ ¿Universidade de São Paulo/ESALQ - Depto. de Ciência e \\ Tecnologia de Alimentos, C.P. 09 - 13418-900 - Piracicaba, \\ SP - Brasil. \\ *Corresponding author <ana.abud@gmail.com>
}

Edited by: Luís Guilherme de Lima Ferreira Guido

Received May 25, 2020

Accepted August 23, 2020
ABSTRACT: The large scale of mango production allows for the application of immediate technologies to minimize post-harvest losses and add even more value to the fruit chain. As a consequence of feasible applications, the production of alcoholic beverages through fermentation and distillation has been elaborated, resulting in a supply of products with different characteristics. This study aimed to monitor the development of a distilled mango beverage and its profile for consumption. The mangoes were selected, pulped and subjected to physicochemical characterization and, subsequently, to fermentation and distillation processes where the kinetics were monitored, and the beverage obtained was compared to similar products found in the literature. During column distillation, the relationship between the temperature profile and the alcohol content was observed, allowing for careful selection of each fraction of the distillate and the establishment of a standard for future distillations. As regards the fraction of interest, good results were obtained in terms of composition with compounds such as methanol and acetaldehyde in minimal quantities, indicating a product that can be consumed without health risks. The small amount of studies following the same line of research confirms the potential mango pulp named Tommy Atkins for the formulation of alcoholic products.

Keywords: Mangifera indica, distillation, spirit, chemical composition

\section{Introduction}

The Brazilian northeast is characterized as a semi-arid area of climatic conditions favorable to the production of fruit, which contributes significantly to the economic development of the region. There are numerous fruit varieties with specific sensorial characteristics that are still little explored, such as mango (Mangifera indica L.), which has a pleasant taste, color and texture, as well as high nutritional value (Pommer and Barbosa, 2009; Fukuda et al., 2014).

In 2018, Brazil had in mango its largest source of revenue among fresh fruit exports, generating $\$ 177.3$ million through the sale of 170.5 million tons. However, its elevated moisture content makes mango highly perishable, with a predisposition to microbiological contamination and reduced postharvest longevity, strongly advocating the use of new technologies in order to reduce losses, add value and generate new products (Sehrawat et al., 2018).

Although sugar cane spirit is the most consumed distillate in Brazil, Brazilian law also allows for the processing of fruit distillates. For these drinks, the alcohol content must be between 36 and $54 \%\left(\mathrm{v} \mathrm{v} \mathrm{v}^{-1}\right)$, at $20^{\circ} \mathrm{C}$, obtained from the simple alcoholic distillate of fruit or by the distillation of fermented fruit must (Coelho et al., 2015). According to Sampaio et al. (2013), fruits and their residues are a significant money-making opportunity awaiting development and application in the beverage industry, due to the presence of sugars that can be converted into ethanol, the low cost and several sensory characteristics (Asquiere et al., 2009). In the literature, there are works on mesquite (Silva et al., 2014), guava (Alves et al., 2008), a mix of mango and passion fruit (Abud et al., 2019) and the residue of jabuticaba (Asquiere et al., 2009).

Distilled beverages can be produced in distillation columns or by copper stills. The columns are used in continuous process industries, on larger scales of production, and manufactured with stainless steel (Ferreira et al., 2018). Due to the absence of copper, there are no complexation reactions of sulfur compounds during the process which could be present in the fresh distilled spirits, that can be lost lost during storage or aging because of their relatively low boiling point, such as Dimethyl sulfide (DMS) (Alcarde, 2014). In addition to non-contamination by copper, the colums avoid problems with corrosion and reduce the amount of equipment maintenance required (Andrade-Sobrinho et al., 2002), preventing the production of ethyl carbamate, a toxic substance (Aresta et al., 2001).

The present study aims to evaluate the production and composition of a distilled mango spirit obtained from a plate column distiller.

\section{Materials and Methods}

The raw material for the distilled beverage was the mango pulp of the variety known as Tommy Atkins, purchased at Sergipe State Supply Center (CEASA)

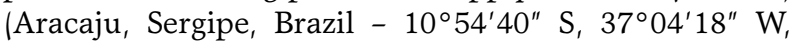
altitude of $4 \mathrm{~m}$ ) and transported to the laboratory, where it was washed, sanitized and bleached by immersion in hot water $\left(75^{\circ} \mathrm{C}\right.$ for $3 \mathrm{~min}$ and subsequent cooling in an ice bath) to aid in preserving, avoiding dimming and reducing viscosity. Next, the manual pulping was carried out followed by storage in plastic containers conditioned in a freezer until processing time. 


\section{Physicochemical characterization of pulp}

The pulped fruit was characterized by physicochemical analyses of moisture content, ash, total soluble solids and acidity, lipids and proteins, carried out in accordance with the rules of the Association of Official Analytical Chemists (AOAC, 2005). All analyses were done in triplicate. The ratio of soluble solids content to acidity was used as a fruit flavor reference. Total reducing sugars (TRS) were determined based on the colorimetric method of 3.5-dinitrosalicylic acid (DNS), after pretreatment with $1.5 \mathrm{M} \mathrm{H}_{2} \mathrm{SO}_{4}$ boiled for $20 \mathrm{~min}$ with occasional stirring to hydrolyze the sugars present (Miller, 1959). The theoretical amount of carbohydrates (Ca) was obtained according to Bueno et al. (2002) by Equation 1, after an analysis of lipids $(L)$, proteins $(P)$, moisture $(M)$ and fixed mineral residue (ashes) $(A)$ as follows:

$C a=100-(L+P+M+A)$

\section{Obtaining and characterizing alcoholic fermentation}

The fermented broth was formulated in a ratio of 1:4 (pulp and water), filtered, and heated to $18^{\circ}$ Brix and the $\mathrm{pH}$ adjusted to 4.5 with sodium carbonate. The wort was supplemented with $\mathrm{MgSO}_{4}\left(0.1 \mathrm{~g} \mathrm{~L}^{-1}\right)$ and $\mathrm{NH}_{4} \mathrm{H}_{2} \mathrm{PO}_{4}(1$ $\mathrm{g} \mathrm{L}^{-1}$ ), pasteurized at $60{ }^{\circ} \mathrm{C}$ for $30 \mathrm{~min}$, and cooled in an ice bath until falling to $35^{\circ} \mathrm{C}$ when $\mathrm{Na}_{2} \mathrm{~S}_{2} \mathrm{O}_{5}\left(0.1 \mathrm{~g} \mathrm{~L}^{-1}\right)$ was added.

The inoculum was conducted by mixing $10 \%$ of the wort volume with the commercial yeast Saccharomyces cerevisiae, in the form of instant dry biological yeast, brand Dona Benta, at a concentration of $1 \mathrm{~g} \mathrm{~L}^{-1}$. Fermentation took place in a 20 vessel, previously sterilized and adapted with a hose to release $\mathrm{CO}_{2}$. The process was carried out at room temperature $\left( \pm 26^{\circ} \mathrm{C}\right)$, without stirring or $\mathrm{pH}$ control, until the soluble solids content $\left({ }^{\circ}\right.$ Brix) remained constant, according to the methodology proposed by Ribeiro et al. (2015).

Daily aliquots of $40 \mathrm{~mL}$ were collected to follow the fermentation, which lasted seven days. At the end of the fermentation, the vessel was stored under refrigeration $\left(4^{\circ} \mathrm{C}\right)$ to aid the sedimenting of the yeast, and then transferring and obtaining the broth (fermented fruit) for distillation.

Alcoholic fermentation was analyzed for the contents of total soluble solids (TSS), total reducing sugars (TRS), cell growth (X) and product formation (ethanol). Cell growth analysis was measured by absorbance in a spectrophotometer (model LGI-VS-721N), at $600 \mathrm{~nm}$, with a standard curve relating dry weight to absorbance. Ethanol concentration $(\mathrm{P})$ was achieved by the simple distillation method followed by reaction with potassium dichromate (Joslyn, 1970). From the data obtained the substrate conversion was evaluated in cells $\left(\mathrm{Y}_{\mathrm{X} / \mathrm{S}^{\prime}}\right.$ $\left.\mathrm{g} \mathrm{g}^{-1}\right)$, and the productivity in ethanol $\left(\mathrm{P}_{\mathrm{E}^{\prime}} \mathrm{g} \mathrm{L}^{-1} \mathrm{~h}^{-1}\right)$, the maximum specific growth rate $\left(\mu_{\max ^{\prime}} h^{-1}\right)$ and the generation time $\left(\mathrm{T}_{\mathrm{g}^{\prime}} \mathrm{h}\right)$ were determined.

\section{Distillation of the fermented product and obtaining the spirit}

The separation process was carried out in a column distiller in batch mode with a glass flask boiler of $5 \mathrm{~L}$ on the bottom, with dimensions of $0.90 \mathrm{~m}$ in column height and $0.065 \mathrm{~m}$ internal diameter filled with raschig rings (Figure 1).

The transparent column has thermal insulation under vacuum, temperature monitoring and a sample collection system. At the top is the condenser, which is connected to a thermostatic bath. The fractions head, heart and tail were separated according to alcohol content. For this, during distillation, the alcoholic content required monitoring by a DMA 35 portable digital densimeter (Anton Paar), overseeing those samples with values above $60 \%\left(\mathrm{v} \mathrm{v} \mathrm{v}^{-1}\right)$ of alcoholic content belonging to the fraction head, between 60 and $29 \%\left(\mathrm{v} \mathrm{v}^{-1}\right)$ to the fraction heart and between 29 and $3 \%$, the tail fraction.

The fractions were identified and quantified by gas chromatography on a Shimadzu, model QP-2010 PLUS, with a flame ionization detector (GC-FID) in a

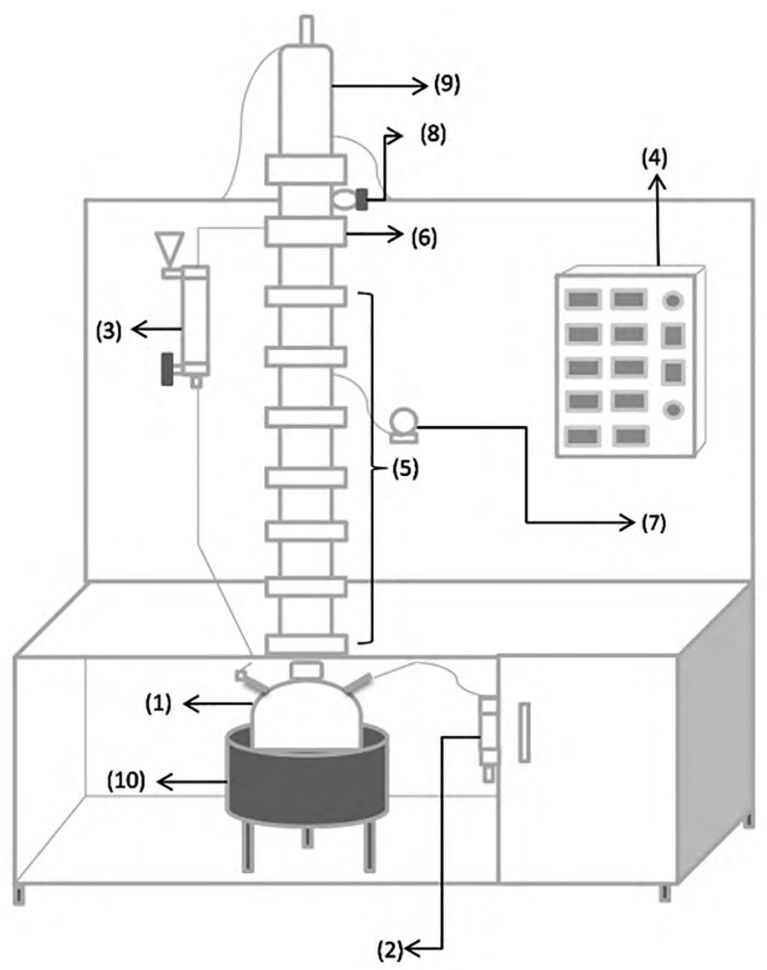

Figure 1 - Scheme of the distillation column with filling, where: (1) boiler, (2) sample collector (present in the boiler), (3) sample collector (product), (4) control panel, (5) collection modules, (6) top module, (7) Bourdon vacuum gauge, (8) refluxer, (9) condenser, (10) heating cover. 
Stabilwax-DA capillary column (Crossbond carbowax polyethylene glycol, $30 \mathrm{~m} \times 0.25 \mathrm{~mm} \times 0.25 \mu \mathrm{L} \mathrm{df}$ ). The injector temperature was $220^{\circ} \mathrm{C}$ and the column temperature was set to $35^{\circ} \mathrm{C}$ for $5 \mathrm{~min}$, increasing up to $220{ }^{\circ} \mathrm{C}$ at a rate of $4{ }^{\circ} \mathrm{C} \mathrm{min}{ }^{-1}$, with retention of 10 $\min$ at $220{ }^{\circ} \mathrm{C}$. The temperature of the detector was $220^{\circ} \mathrm{C}$, with an automatic injection of $1.0 \mu \mathrm{L}$ of sample, following the methodologies of Alcarde et al. (2012) and Bortoletto and Alcarde (2013).

The distillate was submitted to analyses of ethanol, volatile acidity, aldehydes, esters, methyl alcohol, secbutanol alcohol, propyl alcohol, iso-butyl alcohol, n-butyl alcohol, iso-amyl alcohol, higher alcohols, furfural, and congener coefficient, in order to remain in alignment of the limits of Brazilian legislation governance of fruit spirits.

\section{Results and Discussion}

\section{Pulp characterization}

The characterization of mango pulp, in comparison to IN n ${ }^{\circ}$ 01/2000, of the Brazilian Ministry of Agriculture, Livestock and Supply (MAPA), which presents the technical regulation for setting identity and quality standards for pulps, is presented in Table 1.

The soluble solids content in the mango pulp was higher than that obtained by Bezerra et al. (2011), of $12.70^{\circ}$ Brix, value that may vary according to the time of maturation, region and/or harvest. As for the TRS, the value was similar to that obtained by Rocha et al. (2001) in mango fruit, which quantified it at $13.59{\mathrm{~g} 100 \mathrm{~g}^{-1}}^{-1}$ after conversion of the starch to simpler sugars during maturation, pointing out that in an ideal state, the fruit has less starch and more total sugars. According to Bernardes-Silva et al. (2003), the Tommy Atkins variety

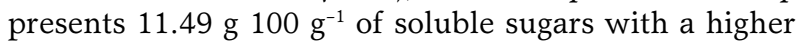
predominance of sucrose, followed by fructose and glucose.

Citrus is the one organic acid that is in the greatest abundance. Because they are determinant properties for acid fruit balance, low $\mathrm{pH}$ values indicate high acidity and vice-versa (Daudt and Fogaça, 2008). In the

Table 1 - Characterization of mango pulp.

\begin{tabular}{|c|c|c|}
\hline Parameters & $\begin{array}{l}\text { Brazilian Legislation } \\
\text { (IN 01/2000) }\end{array}$ & Mango pulp \\
\hline TSS ( ${ }^{\circ}$ Brix) & $\min 11.0$ & $14.8 \pm 0.1$ \\
\hline $\mathrm{pH}$ & $3.3-4.5$ & $4.5 \pm 0.1$ \\
\hline Acidity $\left(\mathrm{g}_{\text {citric acid }} \mathrm{g}^{-1}\right.$ ) & $\min 0.32$ & $0.18 \pm 0.01$ \\
\hline Ratio (TSS/Acidez) & - & 80.77 \\
\hline TRS (g $100 \mathrm{~g}^{-1}$ ) & $\max 17.0$ & 13.1 \\
\hline Moisture (g $100 \mathrm{~g}^{-1}$ ) & - & $84.83 \pm 0.03$ \\
\hline Ashes $\left(\mathrm{g} 100 \mathrm{~g}^{-1}\right.$ ) & - & $0.40 \pm 0.04$ \\
\hline Lipids (g $100 \mathrm{~g}^{-1}$ ) & - & $1.41 \pm 0.01$ \\
\hline Proteins (g $100 \mathrm{~g}^{-1}$ ) & - & $0.71 \pm 0.06$ \\
\hline Carbohydrates (g $100 \mathrm{~g}^{-1}$ ) & - & 12.65 \\
\hline
\end{tabular}

mango pulp, the acid value was lower than allowed, being adjusted at the stage of preparing the must for fermentation together with the sugar content to generate better conditions for the microrganism used.

Moisture was close to that found by Bon et al. (2010) when evaluating the thermophysical properties of the Tommy Atkins species, finding a content of 83.7 g $100 \mathrm{~g}^{-1}$. The ash content of the fruit is in accordance with the Brazilian table of food composition, $0.3 \mathrm{~g} 100$ $\mathrm{g}^{-1}$ for the Tommy Atkins species, a value lower than

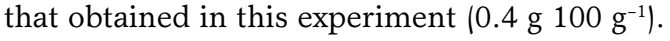

The amount of lipids was higher than that obtained

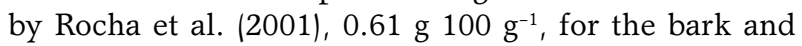
pulp of the same species of mango.

In the fermentation stage, the fermentable carbohydrates present in the raw material are used by the yeasts and converted into primary products, such as ethanol and $\mathrm{CO}_{2}$, and secondary ones, such as esters, acids and higher alcohols, which add organoleptic properties to the beverage (Araújo et al., 2003).

\section{Fermentation kinetics}

During the fermentation daily aliquots were removed for analysis and monitoring of the process (Figure 2A and $\mathrm{B})$.
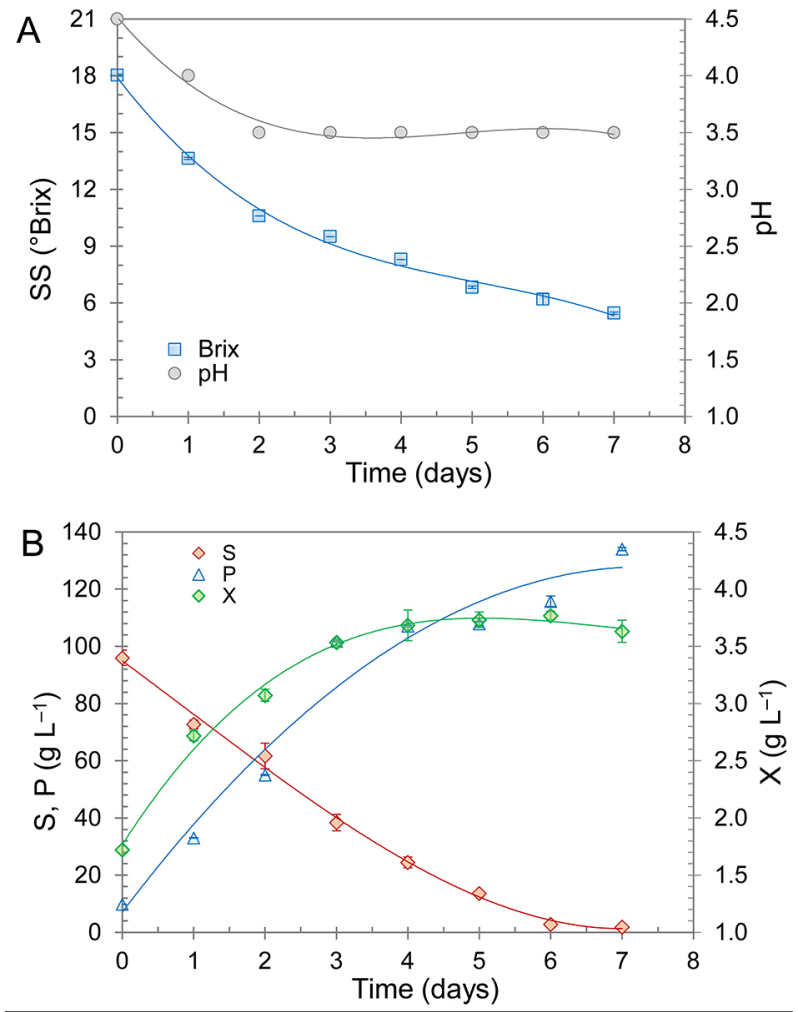

Figure 2 - Fermentation kinetics of mango (A) Soluble solids and $\mathrm{pH}$ throughout the process; (B) Relationship between substrate consumption, growth rate and ethanol production. 
The fermentation lasted seven days. The broth started with a value of $18.0 \pm 0.06{ }^{\circ}$ Brix and at the end of the process, when kept constant, reached $5.5 \pm 0.06$ ${ }^{\circ}$ Brix. As regards $\mathrm{pH}$ behavior, a fall was observed in the first three days, declining to a $\mathrm{pH}$ of 3.5 on the third day until the end of the fermentation.

During the process there was an intense decrease in sugar concentration until the fifth day of fermentation, beginning to stabilize soon after. This means that, during fermentation, the sugars are converted to ethanol and carbon dioxide. In the case of the mango, with a higher concentration of sucrose, the yeast breaks the molecule into glucose and fructose to form the product.

Ethanol production was rapid in the fermentation process, with a kinetic profile similar to yeast growth, associating product formation with microbial growth. Alcohol is the most significant product in the fermentation, with ethyl alcohol comprising approximately $95 \%$ in wines, whereas other alcohols, such as methyl, isobutyl, and isoamylic acid make up amounts close to $5 \%$ (Dantas and Silva, 2017).

Through kinetic monitoring, it was possible to make an overall evaluation of the fermentation process, and obtain the yields in cells $\left(\mathrm{Y}_{\mathrm{X} / \mathrm{S}}\right)$, conversion to etanol $\left(\mathrm{Y}_{\mathrm{P} / \mathrm{S}}\right)$, ethanol productivity $\left(\mathrm{P}_{\mathrm{E}}\right)$, the maximum specific growth rate $\left(\mu_{\max }\right)$, and the generation time $\left(\mathrm{T}_{\mathrm{g}}\right)$. These are presented in the chart below (Table 2).

For substrate cell conversions $\left(\mathrm{Y}_{\mathrm{x} / \mathrm{S}}\right)$, growth was below that obtained by Lopes (2005), while the product yield $\left(\mathrm{Y}_{\mathrm{P} / \mathrm{S}}\right)$ obtained was higher than that found by Santos et al. (2013) in the process for obtaining orange spirit $\left(0.50 \mathrm{~g} \mathrm{~g}^{-1}\right)$, and by Lopes et al. (2005) in the study of the production of fermented palm fruit forage 10.39 $\left.\mathrm{g} \mathrm{g}^{-1}\right)$. The ethanol yield $\left(\mathrm{P}_{\mathrm{E}}\right)$ was below these works. The maximum specific rate of cell growth $\left(\mu_{\max }\right)$ was low in relation to that reported by Alves et al. (2008) for Saccharomyces cerevisiae yeasts, (from 0.19 to 0.64 $\left.\mathrm{h}^{-1}\right)$. This is related to the low yield in cells $\left(\mathrm{Y}_{\mathrm{X} / \mathrm{S}}\right)$ and the process in anaerobiosis, with the substrate being consumed for product formation and not for cell growth. The low value found in the fermented mango may explain the time of stabilization of the SS and the consequent longer time till the end of fermentation.

\section{Distillation}

Alcoholic fermentation has components in its composition that have different degrees of volatility. In distillation, it is possible to group these compounds by dividing the process into stages during their

Table 2 - Kinetic evaluation of mango fermentation.

\begin{tabular}{lccccc}
\hline Fermentation & $\mathrm{Y}_{\mathrm{X} / \mathrm{S}}$ & $\mathrm{Y}_{\mathrm{P} / \mathrm{S}}$ & $\mathrm{P}_{\mathrm{E}}$ & $\mathrm{T}_{\mathrm{g}}$ & $\mu_{\text {máx }}$ \\
\hline & $\mathrm{g}_{\text {cell }} g_{\text {substrate }}{ }^{-1}$ & $\mathrm{~g}_{\text {ethanol }} g_{\text {substrate }}{ }^{-1}$ & $\mathrm{~g}_{\text {ethanol }} \mathrm{L}^{-1} \mathrm{~h}^{-1}$ & $\mathrm{~h}$ & $\mathrm{~h}^{-1}$ \\
Mango & 0.02 & 1.19 & 0.82 & 27.52 & 0.03 \\
\hline
\end{tabular}

volatilization, as well as selecting the most appropriate portion within the limits established by Brazilian legislation. As a division parameter, the ethanol content is used, since products with a boiling point lower than that of alcohol belong to the first fraction head, and products above it belong to the tail. The middle portion is known as the heart and is mainly made up of a nontoxic content that is moderately volatile and marketable (Bizelli et al., 2000).

To obtain the distillate and a better separation of the fractions, samples were collected at pre-defined distillation intervals $(5 \mathrm{~min})$ to measure the alcohol content, it is possible to observe the temperature profile during the process and to relate it to each phase.

Figure $3 \mathrm{~A}$ shows the temperature behavior $\left({ }^{\circ} \mathrm{C}\right)$ along the column and Figure $3 \mathrm{~B}$ the ratio of the alcohol content in the process $\left(\mathrm{v} \mathrm{v}^{-1}\right)$, where the lines in red, perpendicular to the time axis, indicate the moment when the cuts for the fractions head, heart and tail were respectively made.

It has been noted that there is a relationship between the temperature profile and the alcohol content throughout the distillation, where in the first phase, the head is formed by more volatile compounds. There is a greater dispersion of temperature in the different modules, separating a distillate with a higher alcohol content during the first minutes of the distillation. This dispersion reduces in the second stage in which
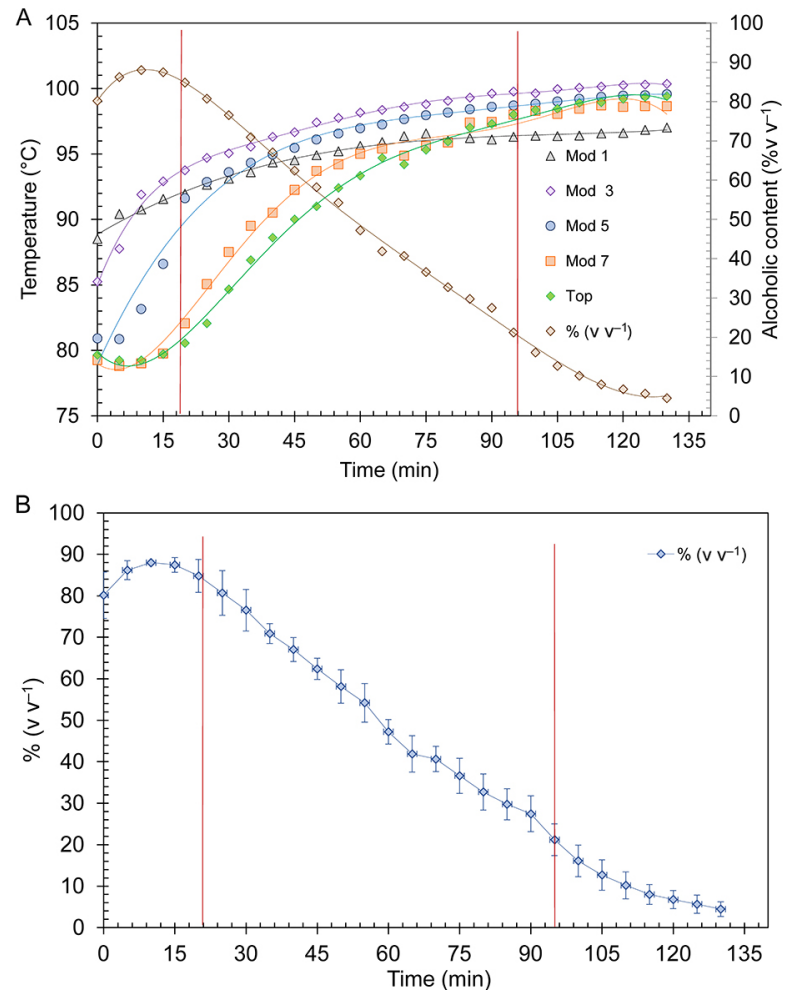

Figure 3 - (A) Temperatures of modules 1, 3, 5, 7 and top; (B) Alcoholic content $\left(\mathrm{v} \mathrm{v}^{-1}\right)$ during distillation. 
the product of interest in the distillation is obtained, namely, the heart. In the third stage, temperatures begin to stabilize and there is a reduction in alcohol content. The cut from the second to the third stage interferes with the sensorial quality of the spirit, because at this stage, the tail presents compounds with sensorially unpleasant characteristics.

All fractions were stored and analyzed for their composition, according to the quality standards established in Brazil, as shown in Table 3.

The alcohol content of the spirit (heart), $52.93^{\circ} \mathrm{GL}$, was very close to the upper limit established by the legislation governing fruit alcoholic beverages (36-54 $\left.{ }^{\circ} \mathrm{GL}\right)$, and above the values found by Silva et al. (2014) in algaroba spirit $\left(42{ }^{\circ} \mathrm{GL}\right)$, and by Alves et al. (2008) in guava spirit $\left(39.9^{\circ} \mathrm{GL}\right)$. The result is influenced by the change in fractions, since, in the search for higher yields, the head fraction was collected in a shorter time.

During distillation, substances that interact with alcohol and water (mostly compounds in the beverage) accompany all vapors and are detected at all stages of the process. For example, compounds such as acetaldehyde and ethyl acetate that interact with ethanol are found in greater quantities in the first phase rich in ethanol. At the other end, the tail, with a higher concentration of water, is linked to acids with a hydrophilic profile such as lactic, malic, glycolic, succinic and pyruvic, ethyl lactate and the quality parameter set by legislation, acetic acid. In turn, the median fraction heart has an affinity for both water and alcohol and features in its characterization different compounds in portions that allow for commercialization of the drink (Serafim et al., 2012).

Acetic acid is a common by-product formed during fermentation, expressed in volatile acidity, this is the main component of the acidic fraction of spirits, and high volatile acidity may indicate the presence of undesirable microorganisms after preparation of the beverage, which compromise the sensorial quality (Cardoso, 2001). As expected, among the fractions, the tail resulted in a higher acid value than the other fractions.

Acetic aldehyde is part of the group of more volatile compounds and, therefore, appeared in greater concentration in the first phase and no trace in the tail. A presence in large quantity in the heart is an indication of failure in separation. However, in this study, the value was relevant when compared to the head but still within the limit allowed (Bortoletto and Alcarde, 2015). The ethyl acetate esters in all fractions complied with the established maximum limit, with relatively low values, and higher content identified in the head. High values of esters are desireable, since they are sensorially important compounds, and confer the characteristic color, flavor and aroma of the raw material that gave rise to them throughout the processing and, even more, in the aging (Barcelos et al., 2007).

The high concentration of methyl alcohol is undesirable in spirit because it is a toxic compound, being the low value obtained in the heart fraction, thus lending a positive character to the drink. It was observed that the largest amount is in the tail, which confirms that it is a fraction with greater presence of toxic and unwanted compounds. The methanol formation occurs mainly when the broth is not filtered and fermentation is carried out in the presence of a considerable amount of bagasse, which did not happen in this study (Vilela et al., 2007).

The higher alcohols are the sum of the n-propyl, isobutyl and isoamyl alcohols, which, if low, will provide a low content of higher alcohols (Bogusz Júnior et al., 2006). They are compounds that combine equally with water and ethanol that can be found by all fractions. In the drink produced, it is noted that the median concentrations decrease from the head to the tail. This can be explained by the fact that these compounds are even more soluble in ethanol than in water, tending to be concentrated mostly in the first two portions (Alcarde

Table 3 - Composition of mango distillate fractions and quality parameters for fruit spirit.

\begin{tabular}{|c|c|c|c|c|}
\hline & Brazilian Legislation (IN 15/2011) & Head & Heart & Tail \\
\hline Alcoholic strength at $20^{\circ} \mathrm{C}\left(\mathrm{v} \mathrm{v}^{-1}\right)$ & $36-54$ & $83.29 \pm 0.04$ & $52.93 \pm 0.03$ & $6.24 \pm 0.01$ \\
\hline Volatile acidity in acetic acid* & $0-150$ & $9.86 \pm 0.40$ & $11.81 \pm 0.49$ & $130.13 \pm 5.41$ \\
\hline Aldehydes in acetic aldehyde* & $\max 30$ & $19.44 \pm 0.90$ & $12.56 \pm 0.58$ & nd \\
\hline Esters in ethyl acetate* & $\max 250$ & $99.76 \pm 3.23$ & $7.08 \pm 0.20$ & nd \\
\hline Methyl alcohol* & $<20$ & $1.09 \pm 0.04$ & $9.58 \pm 0.41$ & $36.54 \pm 1.66$ \\
\hline Sec-butanol alcohol* & $0-10$ & nd & nd & nd \\
\hline Propyl alcohol* & - & $29.64 \pm 1.33$ & $19.86 \pm 0.89$ & $24.68 \pm 1.11$ \\
\hline |sobutyl alcohol* & - & $100.47 \pm 3.71$ & $34.27 \pm 1.51$ & $18.75 \pm 0.77$ \\
\hline N-Butyl alcohol* & $0-3$ & $1.95 \pm 0.07$ & $1.57 \pm 0.06$ & nd \\
\hline Isoamyl alcohol* & - & $399.14 \pm 8.97$ & $300.76 \pm 6.69$ & $16.35 \pm 0.62$ \\
\hline Higher alcohols* & $\max 360$ & $529.25 \pm 14.01$ & $354.88 \pm 9.09$ & $59.78 \pm 2.50$ \\
\hline Furfural + Hydroxumetilfurfural ${ }^{*}$ & $\max 5$ & $0.13 \pm 0.01$ & nd & nd \\
\hline Congeners coefficient ${ }^{*}$ & $200-650$ & $658.43 \pm 18.55$ & $386.34 \pm 10.36$ & $189.90 \pm 7.91$ \\
\hline
\end{tabular}

$\mathrm{nd}=$ Not Detected; ${ }^{*} \mathrm{mg} 100 \mathrm{~mL}^{-1}$ of anhydrous alcohol. 
et al., 2012). The same dynamic occurred where mango and passion fruit were used as raw material to obtain a spirit mix, with the profile of the compounds resulting in a decrease in higher alcohols in the same order of the fractions (Abud et al., 2019). A sum of 704.75 for the head, 299.59 for the heart and 53.53 for the tail was obtained, values also expressed in $\mathrm{mg} 100 \mathrm{~mL}^{-1}$ of anhydrous alcohol.

Metabolic products developed from yeast growth are influenced by the conditions under which the fermentation process was submitted, the quantity and viability of the inoculum, the temperature and by the final alcohol content (Miranda et al., 2008). Mango spirit presented within the limit, but was very close to the maximum value. The presence of furfural, according to Barcelos et al. (2007), reduces the quality of the spirit, affecting its aroma and taste, in addition to being harmful to the organism. In this study, the presence of furfural in mango spirit was only obtained in the first stage, with a minimum value. The coefficient of congeners, sum of volatile acidity, aldehydes, total esters, higher alcohols and furfural and/or hydromethylfurfural (Asquieri et al., 2009), presented values within the legal limits established in Normative Instruction $\mathrm{n}^{\circ}$ 15/2015, with all compositions with higher values, especially the head fraction.

\section{Conclusions}

The shortage of papers on using mango as raw material for fermentation and distillation did not allow for the comparison of data but did reveal the Tommy Atkins mango pulp as a differentiated product for the formulation of alcoholic products. In the process analysis, it was possible to certify the efficiency of the use of the distillation column as an alternative for obtaining distillates, producing a brandy that meets the parameters determined by Brazilian legislation and ensures that the heart fraction, a marketable part, can be consumed without posing any health risk, as it has low levels of toxic compounds in its composition.

\section{Authors' Contributions}

Conceptualization: Oliveira, P.N.; Abud, A.K.S.; Oliveira Júnior, A.M. Data acquisition: Oliveira, P.N.; Alcarde, A.R.; Bortoletto, A.M. Data analysis: Oliveira, P.N.; Alcarde, A.R.; Abud, A.K.S. Design of methodology: Oliveira, P.N.; Abud, A.K.S. Writing and editing: Oliveira, P.N.; Abud, A.K.S.; Oliveira Júnior, A.M.

\section{Acknowledgments}

The authors gratefully acknowledge the Brazilian National Council for Scientific and Technological Development $(\mathrm{CNPq})$ for the research support with scholarship.

\section{References}

Abud, A.K.; Oliveira, P.N.; Alcarde, A.R.; Oliveira Júnior, A.M. 2019. Production of mango and passion fruit mix spirit in a distillation column. Chemical Engineering Transactions 75: 487-492.

Alcarde, A.R.; Monteiro, B.M.S.; Belluco, A.E.S. 2012. Chemical composition of sugar cane spirits fermented by different Saccharomyces cerevisiae yeast strains. Química Nova 35: 16121618 (in Portuguese, with abstract in English).

Alcarde, A.R. 2014. Cachaça: Science, Technology and Art = Cachaça: Ciência, Tecnologia e Arte. Edgard Blucher, São Paulo, SP, Brasil (in Portuguese).

Alves, J.G.L.F.; Tavares, L.S.; Andrade, C.J.; Pereira, G.G.; Duarte, F.C.; Carneiro, J.D.S.; Cardoso, M.G. 2008. Development, qualitative evaluate, yield and production cost of guava spirit. Brazilian Journal of Food Technology 11: 64-68.

Andrade-Sobrinho, L.G.; Boscolo, M.; Lima-Neto, B.S.; Franco, D.W. 2002. Ethyl carbamate in alcoholic beverages (cachaça, tiquira, whisky and grape). Química Nova 25: 1074-1077 (in Portuguese, with abstract in English).

Araújo, F.B.; Silva, P.H.A.; Minim, V.P.R. 2003. Sensorial and physical-chemical evaluation of beers deriving from two segments of Brazilian market. Food Science \& Technology 23: 121-128.

Aresta, M.; Boscolo, M.; Franco, D.W. 2001. Cooper (II) catalysis in cyanide conversion into ethyl carbamate in spirits and relevant reactions. Journal of Agricultural and Food Chemistry 49: 2819-2824.

Asquieri, E.R.; Silva, A.G.M.; Candido, M.A. 2009. Jabuticaba fruit aguardente made from skin and sediments resulting from the production of fermented jabuticaba. Food Science \& Technology 29: 896-904.

Association of Official Analytical Chemists - International [AOAC]. 2005. Official Methods of Analysis. 18ed. AOAC, Gaithersburg, MD, USA.

Barcelos, L.V.F.; Cardoso, M.G.; Vilela, F.J.; Anjos, J.P. 2007. Content of ethyl carbamate and other secondary compounds in different spirits produced in three regions of Minas Gerais: South Minas, Zona da Mata and Jequitinhonha Valley. Química Nova 30: 1009-1011 (in Portuguese, with abstract in English).

Bernardes-Silva, A.P.F.; Lajolo, F.M.; Cordenunsi, B.R. 2003. Evolution of starch and soluble sugar contente during development and ripening of different mango cultivars. Food Science \& Technology 23: 116-120.

Bezerra, T.S.; Costa, J.M.C.; Afonso, M.R.A.; Maia, G.A.; Clemente, E. 2011. Physicochemical evaluation and mathematical models for the prediction of the hygroscopic behavior of mango powder. Ceres 58: 278-283 (in Portuguese, with abstract in English).

Bizelli, L.C.; Ribeiro, C.A.F.; Novaes, F.V. 2000. Double distillation of sugar cane spirit: cooper and total acidity contents. Scientia Agricola 57: 623-627 (in Portuguese, with abstract in English).

Bogusz Júnior, S.; Ketzer, D.C.M.; Gubert, R.; Andrades, L.; Gob, A.B. 2006. Chemical composition of the sugar cane spirit "cachaça" produced in the northeast area of Rio Grande do Sul. Brasil. Food Science \& Technology 26: 793-798. 
Bon, J.; Váquiro, H.; Benedito, J.; Telis-Romero, J. 2010. Thermophysical properties of mango pulp (Mangifera indica $L$. cv. Tommy Atkins). Journal of Food Engineering 97: 563-568.

Bortoletto, A.M.; Alcarde, A.R. 2013. Congeners in sugar cane spirits aged in casks of different woods. Food Chemistry 139: 695-701.

Bortoletto, A.M.; Alcarde, A.R. 2015. Assessment of chemical quality of Brazilian sugar cane spirits and cachaças. Food Control 54: 1-6.

Bueno, M.S.; Lopes, M.R.V.; Graciano, R.A.S.; Fernandes, E.C.B.; Garcia-Cruz, C.H. 2002. Quality evaluationof frozen fruit pulp. Revista do Instituto Adolfo Lutz 61: 121-126 (in Portuguese, with abstract in English).

Cardoso, M.G. 2001. Production of Sugarcane Spirits = Produção de Aguardente de Cana-de-Açúcar. Editora UFLA, Lavras, MG, Brazil (in Portuguese).

Coelho, E.; Vilanova, M.; Genisheva, Z.; Oliveira, J.M.; Teixeira, J.A.; Domingues, L. 2015. Systematic approach for the development of fruit wines from industrially processed fruit concentrates, including optimization of fermentation parameters, chemical characterization and sensory evaluation. LWT - Food Science \& Technology 62: 1043-1052.

Dantas, C.E.A.; Silva, J.L.A. 2017. Umbu wine: Production, fermentative kinetics and physicochemical characterization. HOLOS 2: 108-121 (in Portuguese, with abstract in English).

Daudt, C.E.; Fogaça, A.O. 2008. Effect of tartaric acid upon potassium, total acidity and $\mathrm{pH}$, during the vinification of Cabernet Sauvignon grapes. Ciência Rural 38: 2345-2350 (in Portuguese, with abstract in English).

Ferreira, N.L.; Chic, I.R.A.; Aguiar, J.M.; Ota, R.S.; Costa, T.R. 2018. Study of isobutane-hexene separation: a real petrochemical industry case. The Journal of Engineering and Exact Sciences 4: 1.

Fukuda, S.; Yasunuga, E.; Nagle, M.; Yuge, K.; Sardsud, V.; Spreer, W. 2014. Modelling the relationship between peel colour and the quality of fresh mango fruit using random Forests. Journal of Food Engineering 131: 7-17.

Joslyn, M.A. 1970. Tannins and related phenolics. p. 701-725. In: Joslyn, M.A., ed. Methods in food analysis. Academic Press, New York, NY, USA.

Lopes, R.V.V.; Rocha, A.S.; Silva, F.L.H.; Gouveia, J.P.G. 2005. Application of factorial design for optimization of the study of the production of fermentation of the prickly pear cactus fruit. Revista Brasileira de Produtos Agroindustriais 7: 25-32 (in Portuguese, with abstract in English).

Miller, G.L. 1959. Use of dinitrosalicylic acid reagent for determination of reducing sugar. Analytical Chemistry 31: 426-428.

Ministério da Agricultura, Pecuária e Abastecimento [MAPA]. 2000. Normative Instruction $n^{\circ} 1$ : Approve the General Technical Regulation for setting Identity and Quality Standards for Fruit Pulp = Instrução Normativa $\mathrm{n}^{\circ}$ 1: Aprovacão do Regulamento Técnico Geral para o estabelecimento de Padrões de Identidade e Qualidade para Polpa de Frutas. Diário Oficial da União, Brasília, 10 Jan 2000, Seção 1, p. 54 (in Portuguese).
Ministério da Agricultura, Pecuária e Abastecimento [MAPA]. 2011. Normative Instruction $\mathrm{n}^{\circ}$ 15: Complementation of Identity and Quality Standards for Distilled Alcoholic Beverages, Marketed throughout the National Territory = Instrução Normativa ${ }^{\circ}$ 15: Complementação dos Padrões de Identidade e Qualidade para Bebidas Alcoólicas Destiladas, Comercializadas em todo o Território Nacional. Diário Oficial da união, Brasília, 1 Abr 2011, Seção 1 (in Portuguese).

Miranda, M.B.; Martins, N.G.S.; Belluco, A.E.S.; Horii, J.; Alcarde, A.R. 2008. Chemical profile of aguardente - Brazilian sugar cane alcoholic drink - aged in oak casks. Food Science \& Technology 28: 84-89.

Pommer, C.V.; Barbosa, W. 2009. The impact of breeding on fruit production in warm climates of Brazil. Revista Brasileira de Fruticultura 2: 612-634.

Ribeiro, L.S.; Duarte, W.F.; Dias, D.R.; Schwan, R.F. 2015. Fermented sugarcane and pineapple beverage produced using Saccharomyces cerevisiae and non-Saccharomyces yeast. Journal of the Institute of Brewing 121: 262-272.

Rocha, R.H.C.; Menezes, J.B.; Morais, E.A.; Silva, G.G.; Ambrósio, M.M.Q.; Alvez, M.Z. 2001. Use of the starch degradation index for determining maturity in mango "Tommy Atkins". Revista Brasileira de Fruticultura 23: 302-305 (in Portuguese, with abstract in English).

Sampaio, A.; Dragone G.; Vilanova, M.; Oliveira, J.M.; Teixeira, J.A.; Mussatto, S.I. 2013. Production, chemical characterization, and sensory profile of a novel spirit elaborated from spent coffee ground. LWT - Food Science \& Technology 54: 557-563.

Santos, C.C.A.A.; Duarte, W.F.; Carreiro, S.C.; Schwan, R.F. 2013. Inoculated fermentation of Orange juice (Citrus sinensis L.) for production of a citric fruit spirit. Journal of the Institute of Brewing 119: 280-187.

Sehrawat, R.; Prabhat, K.N.; Barjinder, P.K. 2018. Quality evaluation and drying characteristics of mango cubes dried using low-pressure superheated steam, vacuum and hot air drying methods. LWT - Food Science \& Technology 92: 548555.

Serafim, F.A.T.; Silva, A.A.; Galinaro, C.A.; Franco, D.W. 2012. Chemical profile comparison of sugarcane spirits from the same wine distilled alembics and columns. Química Nova 35: 1412-1416 (in Portuguese, with abstract in English).

Silva, D.P.D.; Souza, J.P.; Cavalcanti, R.M.F.; Clementino, L.C.; Souza, B.R.S.; Brito, A.F.S.; Queiroz, J.C.F. 2014. Artesanal production of brandy from mesquite (Prosopis juliflora) and its acceptance for consumers. Revista Saúde \& Ciência Online 3: 329-339 (in Portuguese, with abstract in English).

Vilela, F.J.; Cardoso, M.G.; Masson, J.; Anjos, J.P. 2007. Determination of the physical-chemical composition of homemade cachaças produced in the South of Minas Gerais and their mixtures. Ciência e Agrotecnologia 31: 1089-1094 (in Portuguese, with abstract in English). 